\title{
Scanning electron microscopy of the attachment of Treponema pallidum to nerve cells in vitro
}

\author{
LILLIAN A REPESH,* T J FITZGERALD, + S GEORGE OAKES, $\neq$ AND \\ R S POZOS \\ From the Departments of *Biomedical Anatomy, +Medical Microbiology and Immunology, and \\ $¥$ Physiology, University of Minnesota School of Medicine, Duluth, Minnesota, USA
}

SUMMARY Treponema pallidum (Nichols strain) was incubated with cultured nerve cells derived from rat embryos. Primary cultures were established from dorsal root ganglia, superior cervical ganglia, and spinal cord. Using phase contrast microscopy treponemes were seen to interact with the nerve cells in a similar manner to other cultured mammalian cells. Organisms began to attach within minutes after inoculation, actively motile organisms attached at the tip of one end, higher numbers of organisms attached with continued incubation, and attached organisms survived longer than unattached organisms. $T$ pallidum attached both to nerve cell bodies and to neuronal processes of each of the three nerve cell cultures. As shown by scanning electron microscopy the mechanism of attachment was identical to that of cultured cells derived from rabbits testis, rat skeletal muscle, and human cervical carcinoma. There was no indentation or swelling of the cultured cell surface at the point of attachment, just a close physical proximity of organisms and cells. These techniques provide a biological means of studying the in-vitro detrimental influences of micro-organisms on nerve tissue.

\section{Introduction}

Clinical manifestations of tertiary and congenital syphilis frequently result from treponemal damage to the central nervous system. Parenchymatous neurosyphilis is characterised by pronounced destruction of the cerebral cortex, dorsal nerve roots, and spinal cord. Three reports have indicated that Treponema pallidum is also present within nerve tissue in primary syphilis, although nerve damage is not apparent. Gregoriew ${ }^{1}$ demonstrated treponemes in the endoneurium and perineurium of nerve fibres, and Ovcinnikov and Delektorskij ${ }^{2}$ observed treponemes in various parts of nerve fibres. Wrzolkowa and Kozakiewicz ${ }^{3}$ showed slight degeneration of axon terminals in lesion material; treponemes, however, were not observed in this tissue.

$T$ pallidum attaches to numerous types of cultured mammalian cells. ${ }^{45}$ This attachment appears to be related to pathogenesis, ${ }^{6}$ and similar attachment to host tissues in vivo may be critical in initiating disease. $^{78}$ To this point, treponemes have been

\footnotetext{
Address for reprints: Dr T J Fitzgerald, Department of Medical Microbiology and Immunology, University of Minnesota School of Medicine, Duluth, Minnesota 55812, USA
}

Accepted for publication 17 January 1982 shown to attach to at least 40 different types of cultured cells derived from testis, skin, cervix, kidney, spleen, lung, urethra, lymph node, cornea, liver, prepuce, nose, footpad, and ear. ${ }^{9}$ This is in accordance with the syphilitic disease process in which $T$ pallidum infects most tissues of the body.

The in-vitro interaction of treponemes with cultured cells derived from nerve tissue has not been studied. The organisms do attach to a C-6 cell line derived from rat glioma. ${ }^{10}$ Glial cells, however, are non-neuronal cells that provide structural support but do not transmit nerve impulses. Recently, techniques have been reported for culturing neuronal cells from embryonic tissues. To our knowledge, there is only one report of the in-vitro interaction of micro-organisms with nerve cells; herpes simplex virus damaged cells derived from dorsal root ganglia. ${ }^{11}$ The purpose of this study was to demonstrate the attachment of $T$ pallidum to three different types of nerve cells.

\section{Materials and methods}

T PALLIDUM

The Nichols strain was maintained by intratesticular passage in rabbits. Each testis was inoculated with $1 \times 10^{7}$ to $3 \times 10^{7}$ treponemes. After a satisfactory 


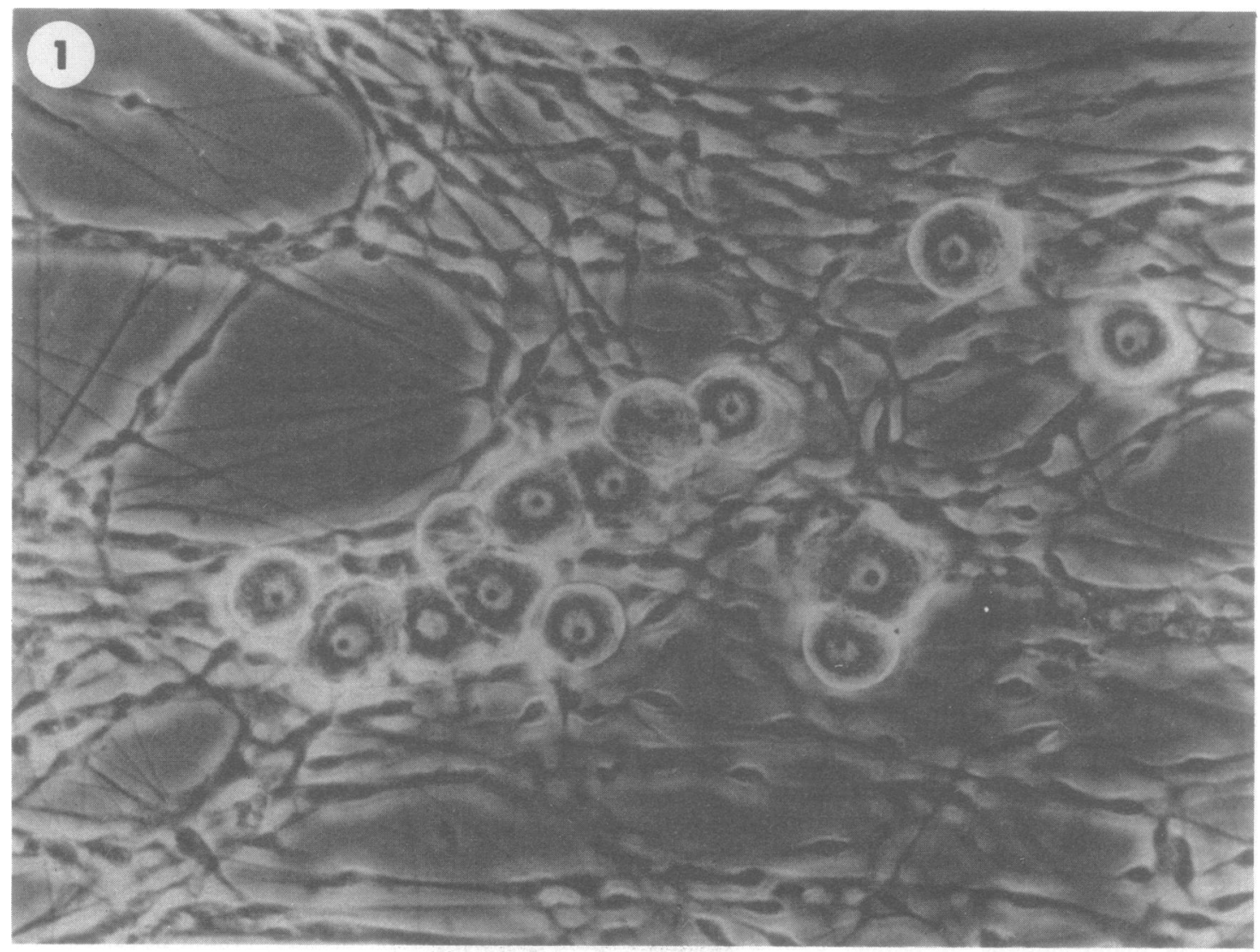

FIG 1 A phase contrast micrograph of a portion of a nerve cell culture sheet from dorsal root ganglia. The nerve cells grew on top of the background fibroblasts and were rounded with prominent nuclear and nucleolar regions. $(\times 1400)$

orchitis had developed in 9-12 days animals were killed and the testes removed, minced with scissors, and extracted at room temperature in tissue culture medium. This medium contained Eagle's minimal essential medium supplemented with $4 \mathrm{mmol} / 1$ $\mathrm{NaHCO}_{3}, 30 \mathrm{mmol} / \mathrm{l}$ HEPES (N-2-hydroxyethylpiperazine $\mathrm{N}-2$ ethanesulphonic acid), and $10 \%$ heated normal rabbit serum $\left(56^{\circ} \mathrm{C}\right.$ for 30 minutes). After 10-20 minutes the preparation was centrifuged at $1000 \times g$ for 10 minutes to sediment particulate matter. This was followed by high-speed centrifugation at $17000 \times g$ for 30 minutes at $4^{\circ} \mathrm{C}$. The pelleted treponemes were then resuspended in fresh medium at $3 \times 10^{7}$ to $6 \times 10^{7}$ organisms $/ \mathrm{ml}$.

\section{NERVE CELLS}

Preparations were made of dorsal root ganglia, superior cervical ganglia, and spinal cords according to the methods of Ransom et al. ${ }^{12}$ The dorsal root ganglia were prepared from 17-19-day-old rat embryos (Sprague-Dawley). Dissected ganglia were placed into $5 \mathrm{ml}$ of $0.25 \%$ trypsin in Hank's balanced salt solution minus calcium and magnesium. After 30 to 45 minutes at $37^{\circ} \mathrm{C}$, the trypsinised cells were washed once and resuspended in Eagle's minimal essential medium supplemented with $600 \mathrm{mg} / 100 \mathrm{ml}$ glucose, $2 \%$ chick embryo extract, $10 \%$ heated horse serum $\left(56^{\circ} \mathrm{C}\right.$ for 30 minutes), $10 \%$ fetal bovine serum, and gentamicin at $50 \mu \mathrm{g} / \mathrm{ml}$. A volume of $0.5 \mathrm{ml}$ of medium was used per embryo. Five drops of this cell suspension were added to $35 \times 10 \mathrm{~mm}$ culture dishes coated with calf skin collagen. Cultures were incubated at $37^{\circ} \mathrm{C}$ in 95\% air and 5\% carbon dioxide. After 24 hours, $1.5 \mathrm{ml}$ medium was added and incubation continued. After the cultures had almost reached confluency, medium containing $10 \mathrm{mmol} / \mathrm{l}$ cytosine arabinoside without fetal bovine serum was added for $\mathbf{4 8}$ hours to decrease the amount of fibroblastic 


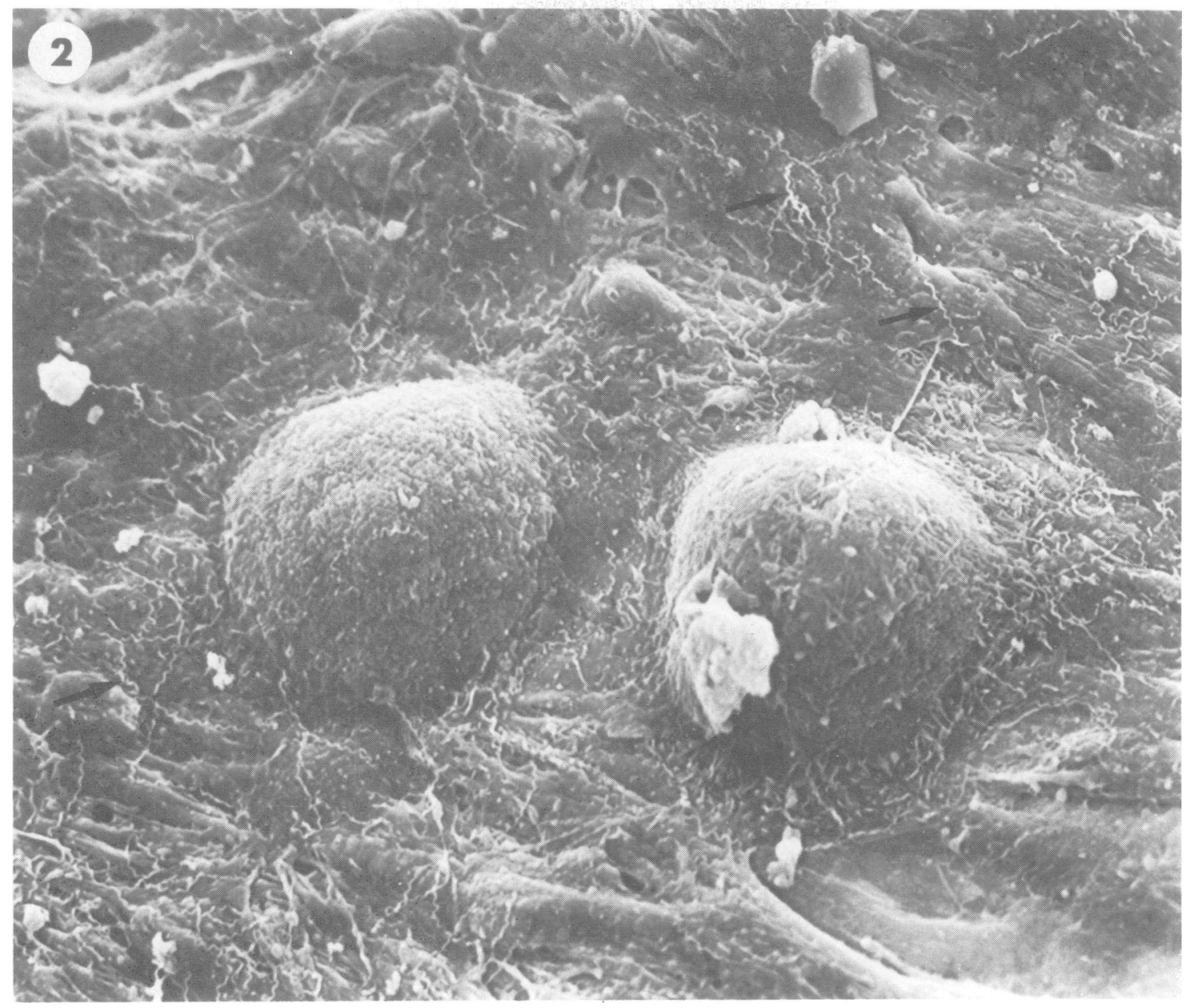

FIG 2 A scanning electron micrograph of a portion of a nerve cell culture sheet from dorsal root ganglia. Two nerve cells were raised and grew over the flattened fibroblasts in the background. Greater numbers of treponemes (arrows) were attached to the fibroblasts. ( $\times 1800)$

cell background. Cytosine arabinoside was then removed and culture medium replaced. These cultures were maintained for 4-6 weeks; medium was changed twice weekly.

Cultures of superior cervical ganglia were prepared from 21-day-old rat embryos. Conditions and laboratory manipulations were similar to those described above. The culture medium was additionally supplemented with $20 \mu \mathrm{g} / \mathrm{ml} 7 \mathrm{~S}$ nerve growth factor (Collaborative Research, Waltham, Massachusetts). A volume of $0.25 \mathrm{ml}$ medium was used per embryo.

Cultures of spinal cord were prepared from 13-14-day-old rat embryos. Meningeal coverings and spinal ganglia were removed and spinal cord tissue cut into 2-mm fragments. Additional procedures were similar to those described for preparation of the cultures of dorsal root ganglia.

TREPONEMAL INOCULATION

Nerve culture cells were gently washed three times with $2 \mathrm{ml}$ treponemal medium. Cultures were then inoculated with $2 \mathrm{ml}$ treponemes and incubated at $37^{\circ} \mathrm{C}$ in an atmosphere of $2.5 \%$ oxygen, $5 \%$ carbon dioxide, and $92 \cdot 5 \%$ nitrogen.

\section{SCANNING ELECTRON MICROSCOPY}

Cultures were rinsed twice in Hank's balanced salt solution and fixed in situ with $3 \%$ glutaraldehyde in $0.1 \mathrm{~mol} / \mathrm{l}$ sodium cacodylate buffer $(\mathrm{pH} 7.35)$ at room temperature for one hour. After a thorough 


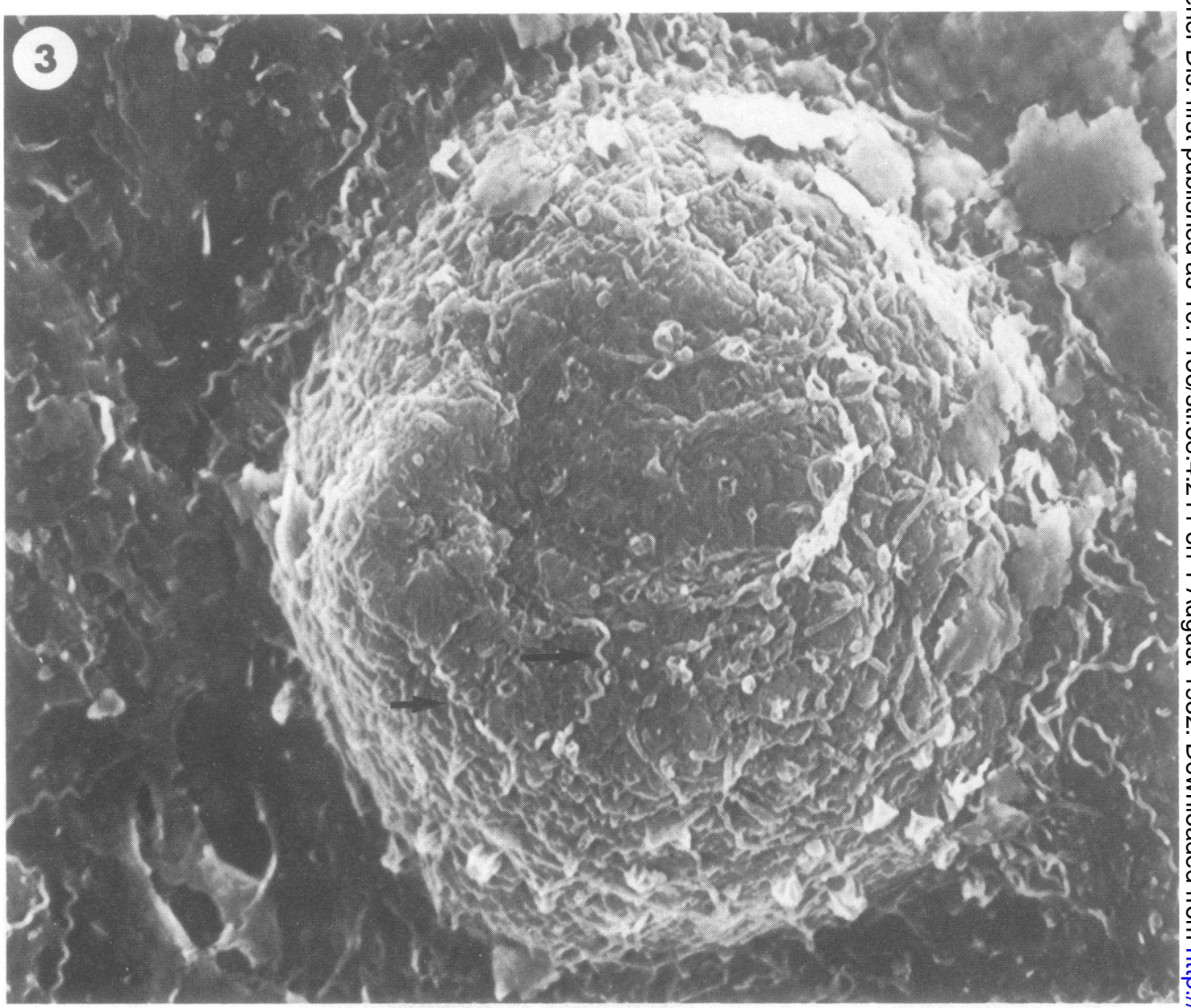

FIG 3 Treponemes (arrows) attached to nerve cells derived from dorsal root ganglia after 45 minutes' incubation. $(\times 3800)$

rinsing with $0 \cdot 1 \mathrm{~mol} / 1$ sodium cacodylate buffer containing $7 \cdot 5 \%$ sucrose, the cultures were post-fixed in $1 \% \mathrm{OsO}_{4}$ with $0 \cdot 1 \mathrm{~mol} / 1$ sodium cacodylate for 30 minutes, washed three times in double distilled water, stained in $2 \%$ uranyl acetate, and dehydrated in aqueous grades of alcohol to $100 \%$. The samples were critical-point dried using $\mathrm{CO}_{2}$, mounted on aluminium stubs with double-stick tape, and coated with gold-palladium using a Hummer II evaporator. Observations were made using an AMR 100 scanning electron microscope.

\section{Results}

In the initial studies phase contrast microscopy was used to characterise treponemal interaction with cultured nerve cells. The neuronal cells can be pre- sumptively identified morphologically. Fig 1 shows $\frac{\delta}{\beta}$ neuronal cells as well as background fibroblasts in a primary culture derived from dorsal root ganglia. $\frac{5}{3}$ The larger, rounded, raised neuronal cells character- $D$ istically grew on top of the monolayer of fibroblasts and showed a well-defined nucleolus. The fibroblasts $N$ which were below the field of focus showed typical fibroblastic, flat, elongated morphology.

The treponemes attached to the neuronal and $\underset{\omega}{N}$ fibroblastic cells. Attachment was identical to that of other cultured mammalian cells. ${ }^{468101314}$ Attachedo organisms retained the typical motility of bending, flexing, and rapidly rotating about their axis without $\stackrel{?}{?}$ moving from their site of attachment. Attachment ${ }^{\circ}$ was usually mediated through the tip of one end of $\frac{P}{\vec{P}}$ the treponeme. Occasionally a few organisms $\cong$ attached at both ends retaining active motility of the $\stackrel{\mathbb{Q}}{\Omega}$ 


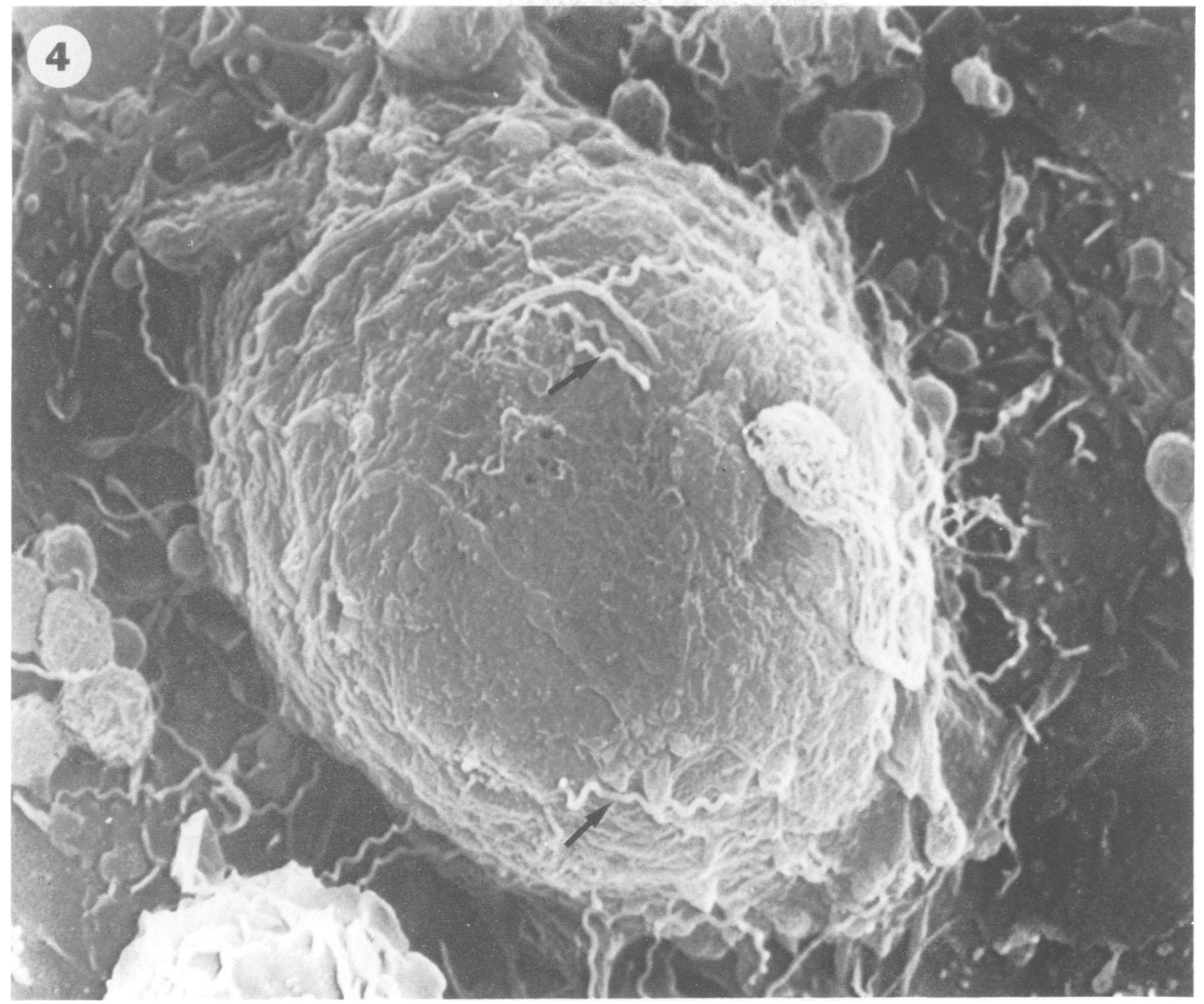

FIG 4 Treponemes (arrows) attached to nerve cells derived from spinal cord. These organisms were also present on the background fibroblasts. Cells were incubated with the organisms for 45 minutes. $(\times 4500)$

middle portion of the organism. Extensive washing of the cultures effectively removed unattached but not attached $T$ pallidum. Organisms began to attach immediately after inoculation, and with increasing periods of incubation higher numbers of treponemes were attached to each cell. In agreement with other studies, attached organisms retained active motility at least $\mathbf{2 4}$ hours longer than unattached organisms; also, heat-inactivated treponemes failed to attach, indicating that attachment is not due to passive sticking or to phagocytic-like activity of the cultured cells. The above findings with cells from dorsal root ganglia were also observed with cells from superior cervical ganglia or spinal cord.

Scanning electron microscopy provided a threedimensional view of treponemal attachment to the nerve cells. $T$ pallidum was added to culture dishes containing cells derived from dorsal root ganglia, superior cervical ganglia, or spinal cord. After incubation for 45 minutes the cultured cells were washed three times with medium to remove unattached treponemes. Fig 2 shows a micrograph at low magnification of cultured cells from dorsal root ganglia. The two nerve cells are readily identified by their rounded raised appearance and by their growth on top of the background monolayer of fibroblasts. Attached treponemes were difficult to see at this low magnification.

Higher magnifications are shown in figs 3-5. All treponemes present were attached; the washing procedures effectively removed unattached treponemes. $T$ pallidum attached to nerve cells from dorsal root ganglia (fig 3) and from spinal cord (fig 4). Larger numbers of organisms attached to nerve cells from 


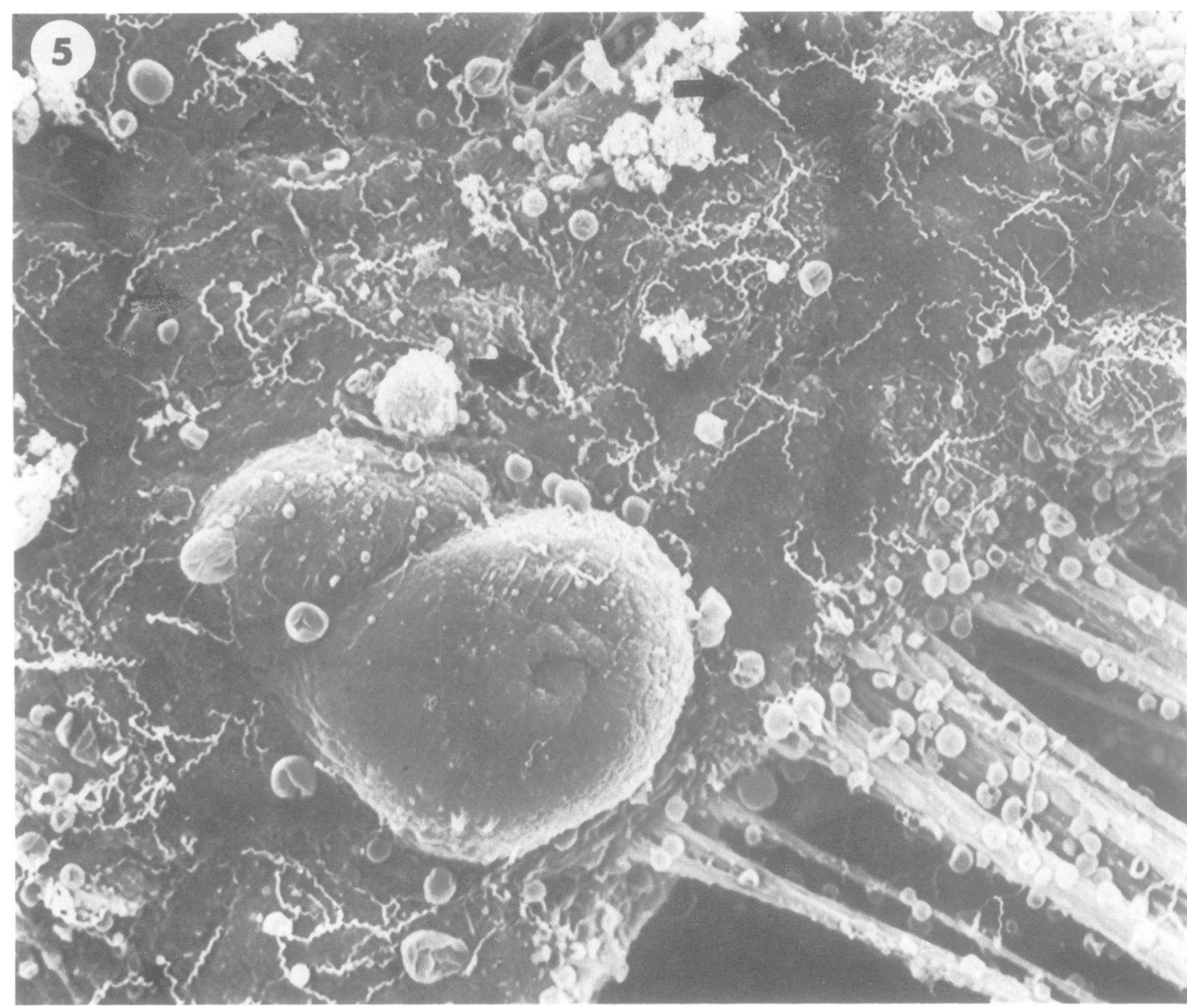

FIG 5 Numerous treponemes (arrows) attached to the surface of a portion of a nerve cell derived from superior cervical ganglia after 45 minutes' incubation. $(\times 1700)$

superior cervical ganglia. Fig 5 shows only a small portion of one of these cells which have a much larger diameter $(100 \mu \mathrm{m})$ than the other two nerve cell types $(30 \mu \mathrm{m})$. In these micrographs the organisms appeared to attach along their entire length. This was artifactual, however, as shown by phase contrast microscopy of actively motile treponemes. $T$ pallidum attached only at its very tip. During fixation the organisms settled on to the cultured cell surface giving the appearance of full length attachment rather than tip attachment.

Besides attaching to the nerve cell body $T$ pallidum also attached to the neuritic processes that extend outward from the nerve cells. Fig 6 shows treponemes attached to a neuronal process emanating from a cell derived from superior cervical ganglia.
Organisms were attached along the full length of the process. Identical findings were observed with 옹 neuritic processes of cells derived from dorsal root $D$ ganglia and spinal cord.

In figs 3-6 nerve cells were incubated with treponemes for 45 minutes. With further incubation 0 increased numbers of organisms attached to each of $N$ the three nerve cell types. Fig 7 shows a portion of a dorsal root ganglia cell after incubation with treponemes for six hours; note the larger number of 0 attached organisms relative to the cell shown in fig 3 .

\section{Discussion}

Syphilitic infection frequently affects nerve tissues. In the primary stage treponemes have been seen 


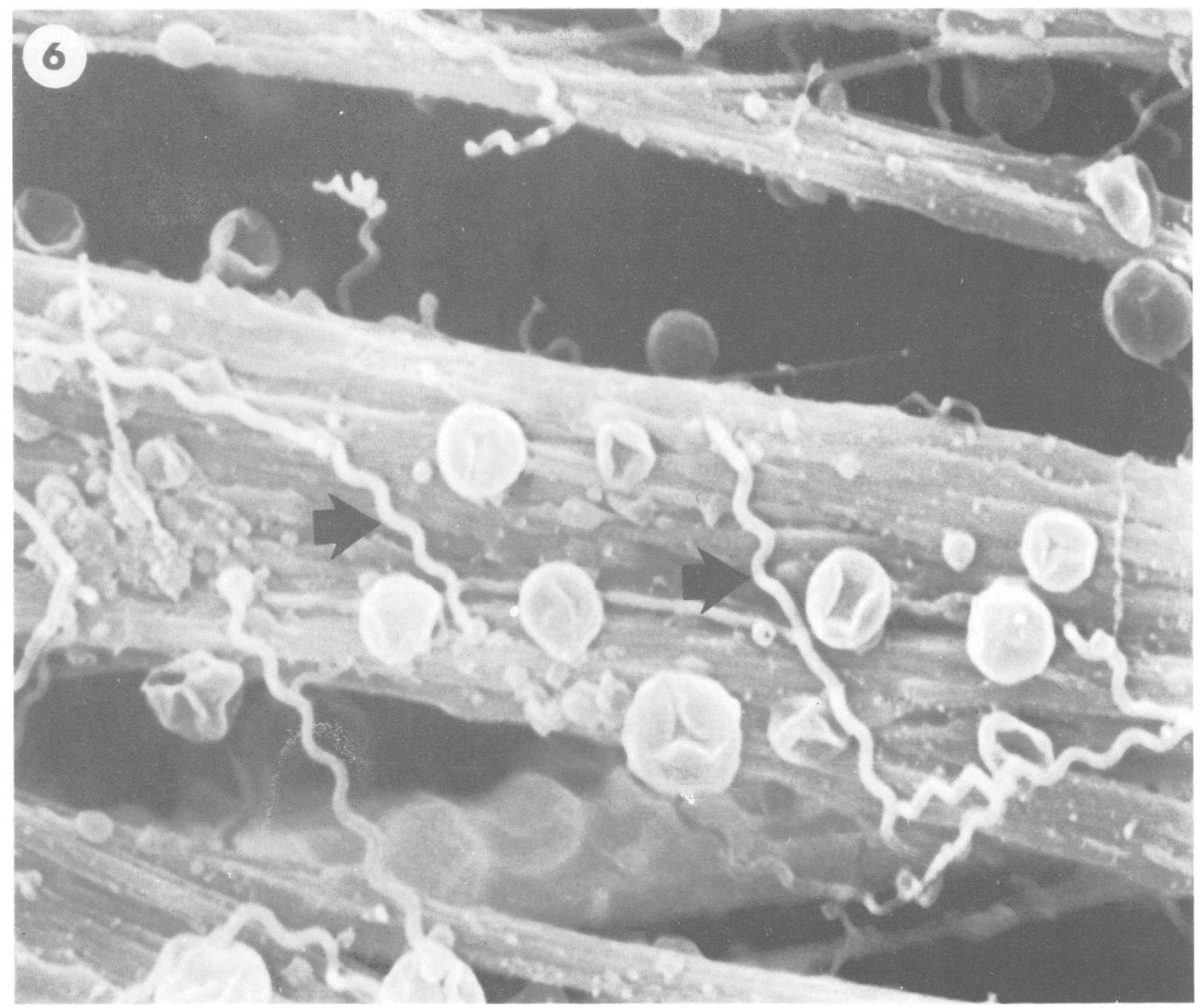

FIG 6 Higher magnification of treponemes associated with neuritic processes extending from a cell derived from superior cervical ganglia. Arruws indicate organisms. ( $\times$ 9000)

within nerve fibres of lesion material ${ }^{12}$; in addition, some axon degeneration has been reported. ${ }^{3}$ In both tertiary and congenital syphilis nerve destruction is readily apparent. Clinical manifestations result from pronounced degeneration of the cerebral cortex, dorsal nerve roots, and spinal cord. The specific mechanisms of treponemal-mediated damage to nerve tissue are unknown. Tissue culture has provided a valuable means of elucidating some aspects of the pathogenesis and immunology of $T$ pallidum. ${ }^{7}$ It has been suggested that attachment of treponemes to host tissues is a critical part of the disease process. ${ }^{467}$ The unique in-vitro system described in this paper should provide useful information about potential in-vivo influences of $T$ pallidum on specific nerve tissues.
Our findings represent the first demonstration of the in-vitro interaction of bacteria with cultured nerve cells. $T$ pallidum attached to nerve cell bodies and to neuritic extensions of cells derived from dorsal root ganglia, superior cervical ganglia, and spinal cord. This attachment is quite similar to that described for other cultured mammalian cells. ${ }^{458101314}$ Organisms began to attach within minutes after inoculation, and with continued incubation higher numbers of treponemes attached. The cultured cells prolonged treponemal survival as shown by the better retention of motility of attached compared with unattached treponemes. In addition, heat-inactivated $T$ pallidum failed to attach. Phase contrast microscopy of viable preparations showed that attachment involved the tip of the organisms interacting 


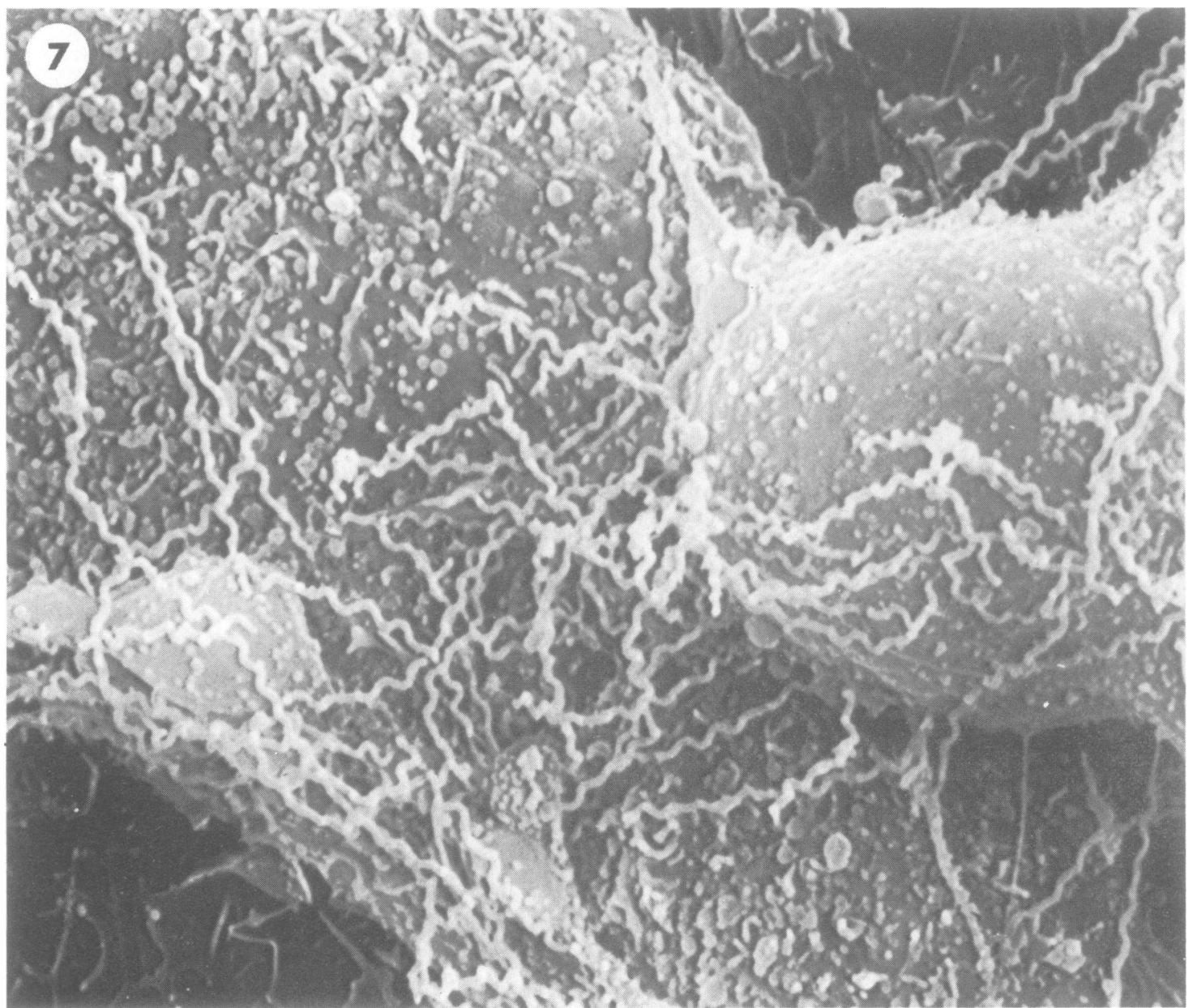

FIG 7 After six hours' incubation treponemes formed a dense network on the surface of a portion of a nerve cell derived from dorsal root ganglia. $(\times 5900)$

with the nerve cell surface. Attached organisms retained characteristic motility of bending, flexing, and rotating without moving from the point of attachment. Scanning electron microscopy of fixed preparations showed that there was no indentation or swelling of nerve surface topography at the point of attachment. This confirms previous scanning electron microscopy of treponemal attachment to cultured cells derived from rabbit testis, rat skeletal muscle, and human cervical carcinoma. ${ }^{8} 1516$

Because appropriate techniques are available, tissues derived from embryonic rats were used. Syphilitic infection of rabbits mimics infection of humans; in contrast, infection of rats results in minimal tissue response. ${ }^{17}$ Overt clinical lesions usually do not occur and it is difficult to detect organisms in tissues. Treponemes in asymptomatic infection can be shown by transfer of lymph node material to rabbits, who subsequently develop syphilitic lesions. ${ }^{17}$ The interaction of $T$ pallidum with cultured cells derived from rabbits is comparable to the interaction with cultured cells derived from species that show minimal syphilitic infection such as rat, mouse, dog, monkey, and pig. ${ }^{61314}$ It is likely that the basis for minimal infection in these animals is not attributed to innate differences within tissues. More probably, the lack of symptomatic infection reflects differences in either serum factors or in more effective humoral and cell-mediated immune responses. ${ }^{9}$ Thus, relevant insights into the pathogenesis of $T$ pallidum should result from these studies using nerve tissue derived from rats. 
We would like to acknowledge the excellent technical assistance of Paul Lima for tissue culture preparations, Eileen Gannon for treponemal preparations, and Anne Utyro for developing and processing the photomicrographs. This research was supported by the Public Health Service and National Institute of Allergy and Infectious Diseases grant AI 16-585, the National Institute of Neurological and Communicative Disorders and Stroke grant NS-13325, and the Minnesota Medical Foundation grant 0762-5836.

\section{References}

1. Gregoriew PS. Uchebnik venericheskich i kojnich belznej. Biomedgiz. NKA USSR; 1938.

2. Ovcinnikov NM, Delektorskij VV. Treponema pallidum in nerve fibres. Br J Vener Dis 1974;51:10-8.

3. Wrzolkawa T, Kozakiewicz J. Ultrastructure of vascular and connective tissue changes in primary syphilis. Br J Vener Dis 1980;56: 137-43.

4. Fitzgerald TJ, Miller JN, Sykes JA. Treponema pallidum (Nichols strain) in tissue culture: cellular attachment, entry, and survival. Infect Immun 1975; 11: 1133-40.

5. Wright MI. Exploratory studies in tissue culture of $T$ pallidum. Proceedings of the 12th International Congress of Dermatology $1963 ; 2: 884-7$.

6. Fitzgerald TJ, Johnson RC, Miller JN, Sykes JA. Characterization of the attachment of Treponema pallidum (Nichols strain) to cultured mammalian cells and the potential relationship of attachment to pathogenicity. Infect Immun 1977; 18: 467-8.
7. Fitzgerald TJ, Miller JN, Sykes JA, Johnson RC. Tissue culture and Treponema pallidum. In: Johnson RC, ed. The Biology of Parasitic Spirochetes. New York: Academic Press Inc, $1976 ; 54-67$

8. Hayes NS, Muse KE, Collier AM, Baseman JB. Parasitism by virulent Treponema pallidum of host cell surfaces. Infect Immun 1977; 17: 174-186.

9. Fitzgerald TJ. Pathogenesis and immunology of Treponema pallidum. Ann Rev Microbiol 1981;35:29-54.

10. Sandok PL, Jenkin HM, Graves SR, Knight ST. Retention of motility of Treponema pallidum (Nichols strain) in an anaerobic cell culture system and in a cell-free system. J Clin Microbiol 1976; 3:72-4.

11. Oakes SG, Ziegler RJ, Pozos RS. Electrophysiological changes in HSV-1 infected dorsal root ganglia neurons in culture. $J$ Exp Neurol Neuropathol 1981;40:380-9.

12. Ransom BR, Neale E, Henkart M, Bullock PM, Nelson PG. Mouse spinal cord in cell culture. I Morphology and intrinsic neuronal electrophysiologic properties. J Neurophysiol 1977; 40:1132-50.

13. Fieldsteel AH, Becker FA, Stout JG. Prolonged survival of virulent Treponema pallidum (Nichols strain) in a cell-free and tissue culture system. Infect Immun 1977; 18:173-82.

14. Kiraly $\mathrm{K}$, Horvath I. Survival of $T$ pallidum under microaerobic conditions in cell and tissue cultures. Zentralbl Bakteriol (Orig A) 1976;235: 500-5.

15. Fitzgerald TJ, Cleveland P, Johnson RC, Miller JN, Sykes JA. Scanning electron microscopy of Treponema pallidum (Nichols strain) attached to cultured mammalian cells. J Bacteriol 1977; 130: 1333-44.

16. Fitzgerald TJ, Repesh LA, Oakes SG. Morphologic destruction of cultured cells mediated through the attachment of Treponema pallidum. Br J Vener Dis 1982;58:1-11.

17. Turner TB, Hollander DH. Biology of the treponematoses. WHO Monogr Ser No 35, 1957. 